\title{
Pelatihan perawatan/service AC untuk masyarakat sekitar Politeknik Penerbangan Indonesia Curug
}

\author{
Yenni Arnas ${ }^{1}$, KGS. M. Ismail ${ }^{1}$, Zulina Kurniawati ${ }^{1}$, Benny Kurnianto ${ }^{1 *}$, Imam Haryadi Wibowo ${ }^{1}$, \\ Nawang Kalbuana ${ }^{1}$
}

${ }^{1}$ Politeknik Penerbangan Indonesia Curug, Tangerang, Banten, Indonesia

*) Korespondensi (e-mail: benny.kurnianto@ppicurug.ac.id )

Received: 13-November-21; Revised: 20- November-21; Accepted: 22- November-21

\begin{abstract}
The trend of using air conditioners, air conditioners or called AC (Air Conditioner) is increasing in the community both in offices and in housing. To keep its performance, air conditioning should be maintained regularly according to the intensity procedure. Hence, the air conditioner can stabilize the air temperature and humidity of the area in accordance with its specification. As the demand for maintenance is growing, the opportunity to become an AC technician is also increasing. Carrying out basic training in AC maintenance can assist people who are interested to become AC technicians. Training participants are expected to gain knowledge of AC installation, $A C$ components and working principles, AC maintenance, and safety standard.
\end{abstract}

Keywords: $A C$, instalation, maintenance.

\section{Abstrak}

Tren penggunaaan penyejuk udara, pendingin udara atau disebut AC (Air Conditioner) semakin meningkat di masyarakat baik di perkantoran maupun di perumahan. Untuk menjaga performa AC agar mampu menstabilkan suhu udara dan kelembapan area, perwatan AC harus dilakukan secara rutin sesuai intensitas penggunaannya. Kebutuhan akan teknisi AC pun dapat dikatakan ikut meningkat. Salah satu kegitan yang dapat dilakukan untuk meningkatkan jumlah teknisi AC adalah dengan melakukan pelatihan dasar perawatan AC. Peserta pelatihan diharapakn memiliki peluang untuk menjadi teknisi $A C$ yang memiliki pengetahuan tentang instalasi, komponen dan prinsip kerja $\mathrm{AC}$, cara memelihara dan merawat $\mathrm{AC}$, dan juga mengetahui standar kesehatan dan keselamatan kerja.

Kata kunci: $A C$, instalasi, perawatan.

How to cite: Arnas, Y., M. Ismail, K., Kurniawati, Z., Kurnianto, B., Haryadi Wibowo, I., \& Kalbuana, N. (2021). Pelatihan perawatan/service AC untuk masyarakat sekitar Politeknik Penerbangan Indonesia Curug. Penamas: Journal of Community Service, 1(2), 90-99. https://doi.org/10.53088/penamas.v1i2.202

\section{Pendahuluan}

Dampak Pandemik Covid-19 masih sangat dirasakan oleh masyarakat Indonesia dan berpengaruh sangat signifikan untuk memperoleh pendapatan (Hendriarto, Mursidi, Kalbuana, Aini, \& Aslan, 2021; Kalbuana \& Kurnianto, 2011; Kalbuana et al., 2021; Nawang Kalbuana, 2020). Salah satu peluang yang dapat dimanfaatkan oleh masyarakat adalah melakukan service AC. AC sering disebut dengan penyejuk udara, pendingin udara, pengkondisi udara, penyaman udara adalah merupakan system atau mesin yang dirancang untuk menstabilkan suhu udara dan kelembaban suatu area (yang digunakan untuk pendinginan maupun pemanasan tergantung pada sifat udara 
pada waktu tertentu) (Husodo, Elektro, \& 2014, n.d.; Pengabdian dan Edukasi Sekolah et al., 2021; Ridhuan \& Refai, 2013).

Beberapa tahun lalu alat penyejuk udara atau Air Conditioner (AC) masih tergolong barang langka yang hanya ditemukan di kantor, hotel, mall atau rumah mewah. Namun, sekarang AC sudah menjadi kebutuhan banyak orang terutama di kota-kota karena meningkatnya suhu udara. Selain itu AC sudah menjadi fasilitas wajib terutama di kamar-kamar hotel, ruang kerja bahkan di rumah-rumah (Buku et al., 2021; Pattiapon et al., 2021; Prasetyo, Rohman, Solihin, Sundoro, \& Kalbuana, 2021; Sumeru \& Sutandi, 2018).

Permintaan jasa perawatan AC pun ikut meningkat seiring pertumbuhan pengguna AC di masyarakat. Politeknik Penerbangan Indonesia Curug (PPIC) yang berlokasi di kecamatan Legok yang terdiri dari beberapa kelurahan yang berada disekitar nya, melihat peluang bagi masyarakat sekitar hendak bekerja menjadi teknisi AC dengan terlebih dahulu meningkatkan pengetahuan atau keterampilan yang dapat mendukung pekerjaan tersebut.

ACS (Air Conditioner System) sendiri merupakan salah satu kompetensi yang dipelajari di program studi Teknik Mekanikal Bandar Udara (TMB) - PPIC. Dengan menyelenggarakan pelatihan perawatan AC sebagai wujud dharma Pengabdian Kepada Masyarakat (PKM), tim PKM program studi TMB telah melaksanakan pengembangan hasil pendidikan dan penelitian yang dapat dimanfaatkan oleh masyarakat sekaligus meningkatkan peluang peserta pelatihan untuk mengembangkan diri dan meningkatkan keterampilan.

Secara khusus, pelatihan yang dilaksanakan meliputi pemeliharaan dan perawatan/service $\mathrm{AC}$ dimana peserta dilatih dan pada akhirnya memiliki pengetahuan tentang kontruksi, instalasi, komponen dan prinsip kerja AC, beserta cara pemeliharaan dan perawatan, dan standar kesehatan dan keselamatan kerja.

\section{Metode Pengabdian}

Metode yang dilakukan dalam pelaksanaan kegitan terdiri atas beberapa tahapan. Pertama, tim melakukan survei lapangan terkait rencana pelaksanaan kegiatan Pengabdian kepada Masyarakat berupa pelatihan keterampilan teknis. Kedua, tim melakukan pendalaman terkait hasil survei dan observasi lapangan, untuk menentukan jenis kegiatan pelatihan yang mampu menjadi solusi permasalahan di masyarakat. Ketiga, tim merencanakan kegiatan pelatihan, dengan menyusun jenis, lingkup, tim dan waktu kegiatan/pekerjaan, serta materi pelatihan. Selanjutnya, tim melaksanaan kegiatan pelatihan. Tim kemudian membuat laporan pelaksanaan pelatihan sebagai kegiatan pengabdian kepada masyarakat.

Kegiatan pengabdian masyarakat juga membutuhkan partisipasi masyarakat sebagai peserta pelatihan. Untuk itu, tim menjadikan calon peserta pelatihan sebagai target survei dan observasi untuk mendapatkan informasi tentang jenis keterampilan yang dibutuhkan masyarakat, metode pelatihan yang mudah dipahami peserta. 
Observasi dilakukan untuk menentukan jenis kebutuhan jasa yang meningkat di masyarakat. Tim kemudian menganalisa potensi jenis jasa yang dapat dijadikan pekerjaan oleh peserta pelatihan nantinya. Tim juga menganalisa keterampilan dasar yang dapat digunakan untuk bekerja di jenis jasa tersebut.

Langkah terakhir dalam pelaksanaan kegitan pengabdian ini adalah evaluasi pada setiap tahapan dengan melakukan observasi dan tanya jawab. Proses evaluasi terhadap proses pelaksanaan pelatihan dilakukan oleh tim PKM dan peserta pelatihan. Proses evaluasi dilakukan terhadap materi dan metode pelatihan. Proses evaluasi di akhir pelaksanaan pelatihan dilakukan dengan pengisian survei oleh peserta pelatihan. Selanjutnya Tim melakukan analisa evaluasi untuk menentukan peluang melaksanakan kegiatan sejenis yang mungkin dapat dilakukan untuk periode berikutnya.

\section{Hasil Pengabdian}

\section{Perencanaan Kegiatan}

Dari hasil survei tahap pertama unutk menentukan rencana kegiatan pelatihan, ditim PKM TMB menemukan bahwa keterampilan dasar yang dibutuhkan peserta pelatihan meliputi pengetahuan tentang kontruksi/instalasi, komponen dan prinsip kerja AC, beserta cara pemeliharaan dan perawatan, pemeriksaan dan penggantian beberapa komponen yang sesuai dengan prosedur yang benar dan standar kesehatan dan keselamatan kerja.

Pada tahap kedua pelaksanaan kegiatan PKM, tim menyusun materi dan rencana pembelajaran. Penyusunan in dilakukan secara daring seperti ditunjukkan pada gambar 1 dibawah ini. Dari hasil kajian tim, pelaksanaan pelatihan dapat dilakukan selama 2 hari dengan tim pengajar berjumlah 13 orang terdiri dari 4 dosen, 1 instruktur dan 8 taruna pendamping.

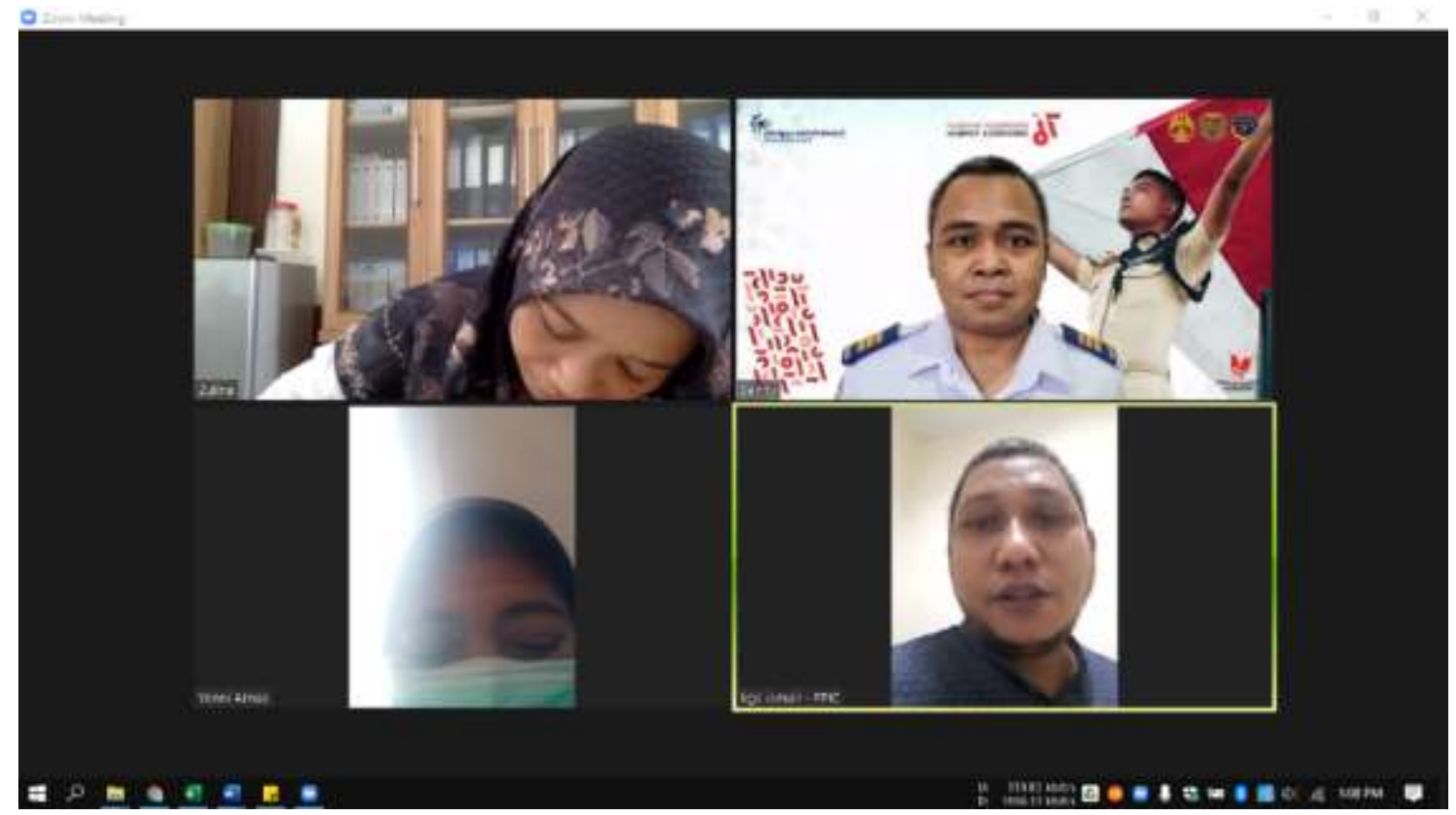

Gambar 1. Rapat Persiapan Tim PKM TMB 
Sedangkan dari observasi lapangan untuk menentukan permasalah mitra, tim menemukan bahwa kebutuhan jasa perawatan $A C$ yang meningkat adalah jenis $A C$ split dengan daya $1 / 2$ PK sampai dengan 2 PK yang bisa digubakan di rumah tinggal. Untuk itu, materi yang disusun dibatasi pada teori dan praktek perawatan dasar AC split.

\section{Pelaksanaan Kegiatan}

Sehubungan dengan waktu pelaksanaan kegiatan pelatihan di tengah pandemic covid19, kegiataan diawali dengan test antigen terhadap para peserta dan tim pengajar untuk mencegah munculnya klaster penularan virus Covid 19. Pengambilan sampel seperti yang ditunjukkan pada gambar 2 dilakukan pada hari pertama pelatihan melalui kerjasama dengan tim kesehatan PPIC.

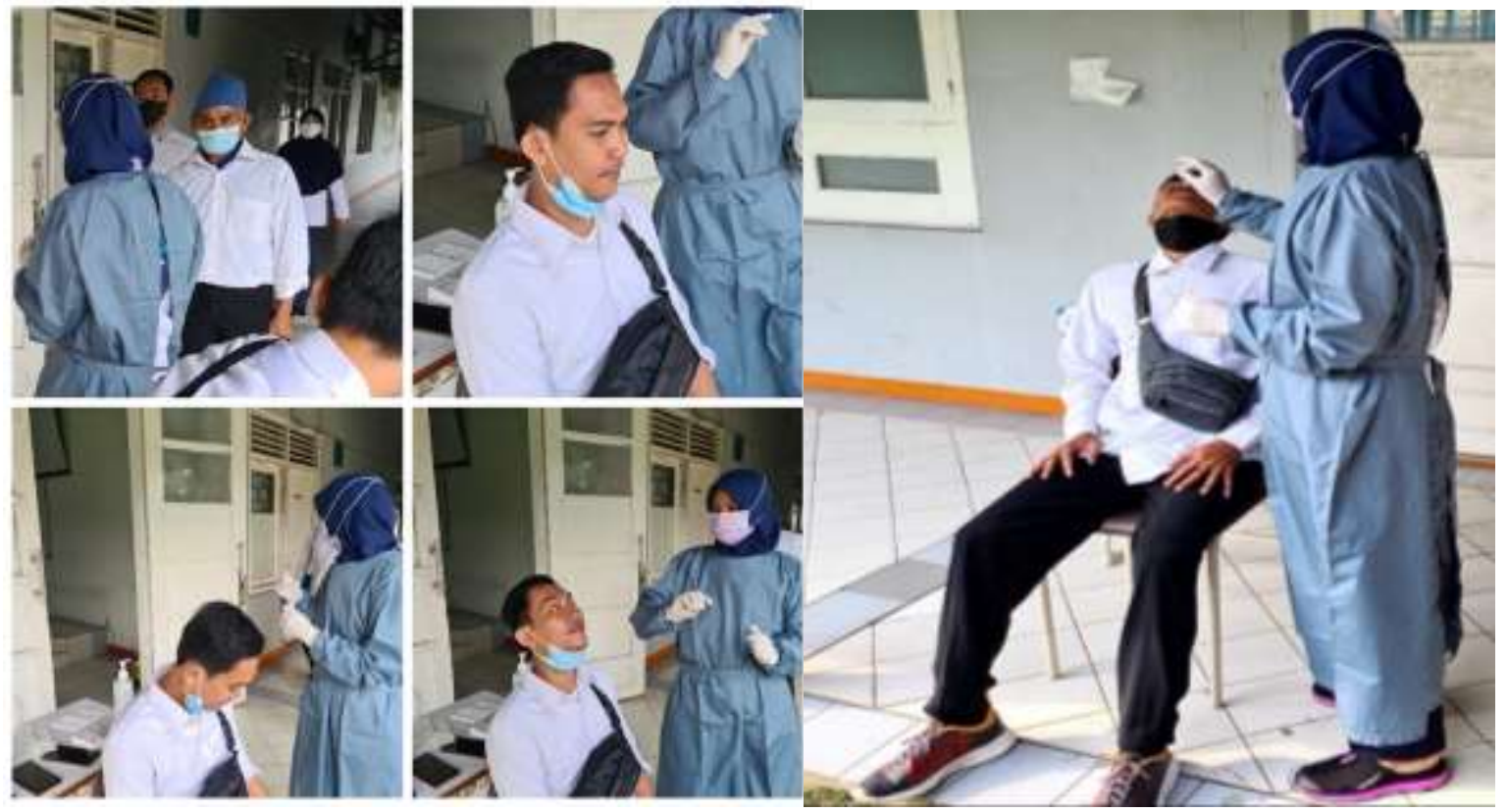

Gambar 2. Test Swap Antigen Peserta Pelatihan dan tim pengajar.

Setelah pelaksanaan swap antigen dan peserta seluruhnya dinyatakan negatif, kegiatan dilanjutkan dengan Pembukaan kegiatan pelatihan yang secara resmi dibuka oleh Kepala Bagian Administrasi Akademik dan Ketarunaan PPIC. Dalam pembukaannya seperti yang ditunjukkan pada gambar 3, Kepala Bagian Administrasi Akademik dan Ketarunaan PPIC mengharapkan kegiatan dapat diikuti peserta selama 2 hari penuh sehingga materi yang disampaikan dapat diterima dengan utuh.

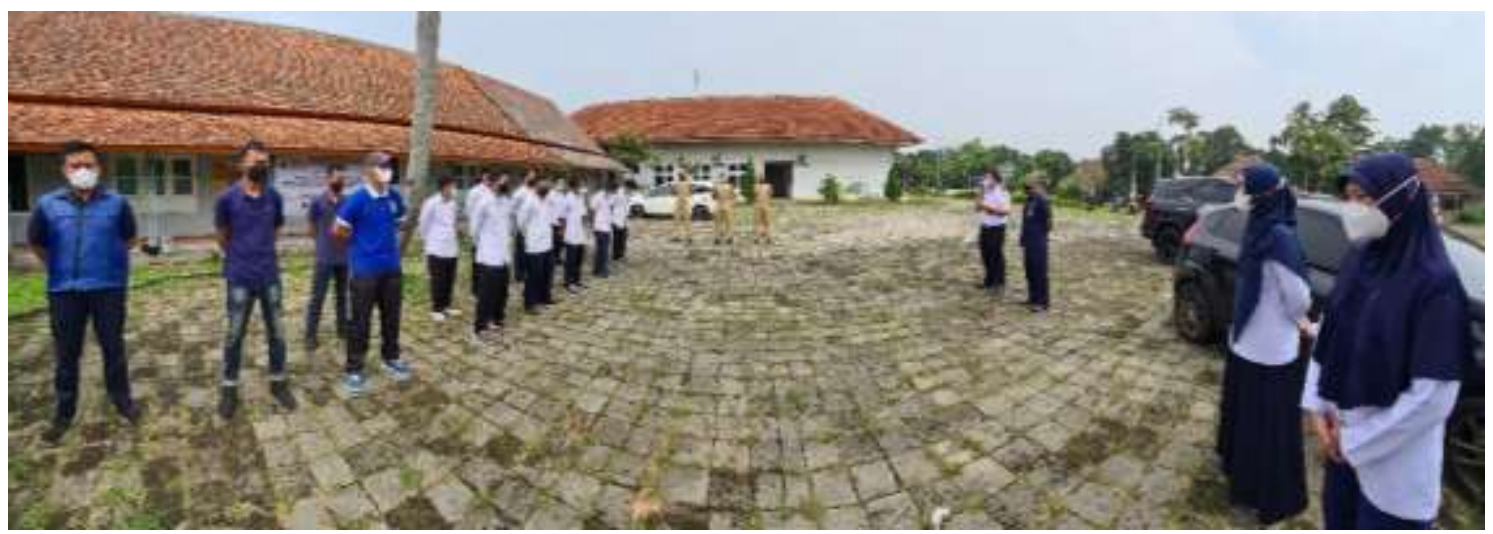


Gambar 3. Pembukaan Kegiatan Pelatihan Perawatan AC

Setelah rangkaian acara pembukaan selesai, kegiatan dimulai dengan pembelajaran teori dasar AC yang meliputi komponen-komponen AC dan cara kerja masing-masing komponen yang disampaikan oleh tim pengajar seperti ditunjukkan pada gambar 4. Dalam sesi ini juga dijelaskan cara mengukur voltase dan arus listrik yang dibutuhkan untuk menginstalasi AC sesuai daya yang diinginkan.

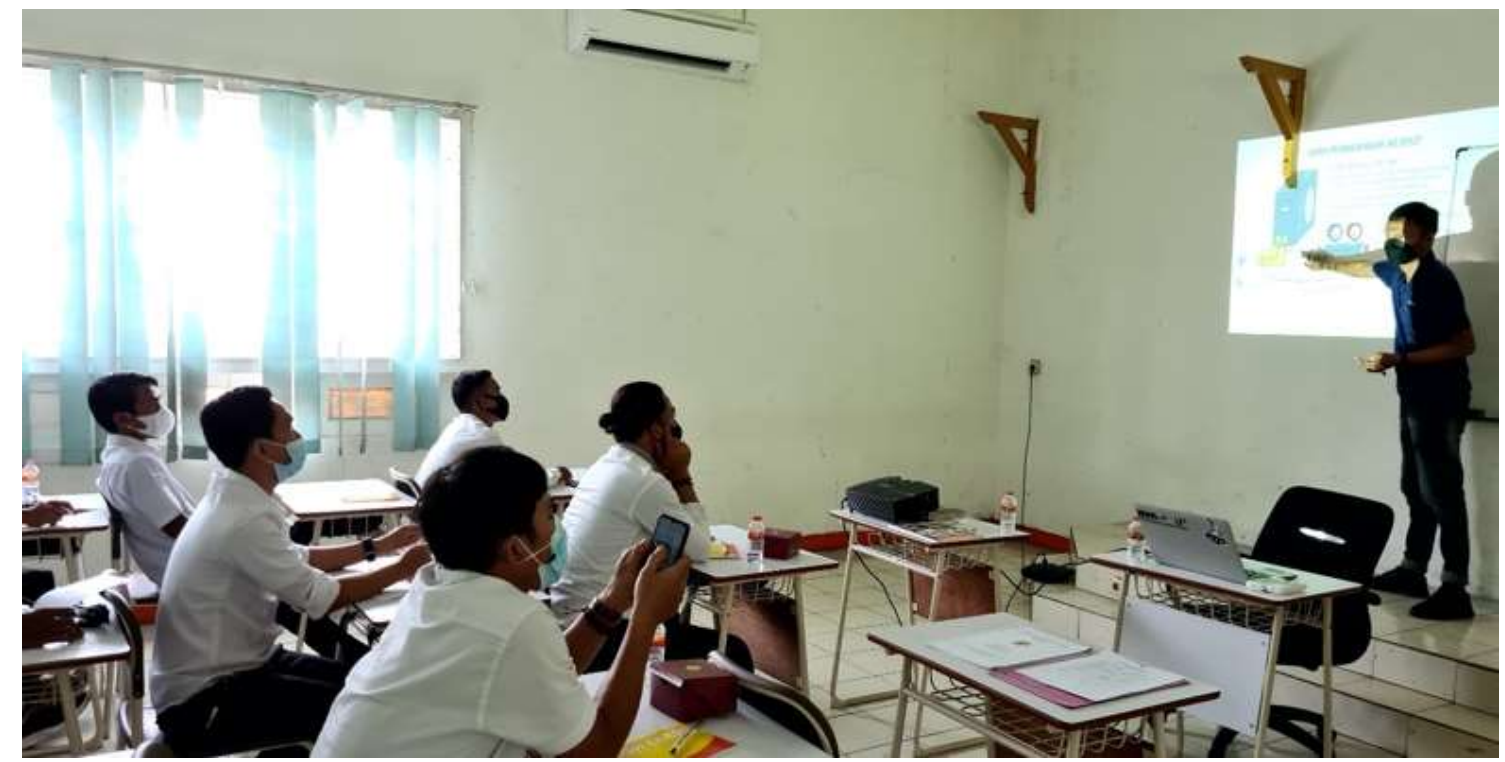

Gambar 4. Pengenalan Dasar AC

Setelah seluruh materi teoritis disampaikan, peserta mulai diajak mempraktekan salah satu teknik yang sering dibutuhkan dalam instalasi AC yang penyambungan pipa. Teknik penyambungan pipa dimulai dari flaring, yaitu mengembangkan salah satu ujung pipa yang akan disambung seperti ditijukkan pada gambar 5. Kemudian kedua ujung pipa dapat disatukan dengan dua cara. Cara pertama dengan brazing, yaitu mengelas pipa dengan menambahkan flux seperti ditinjukkan pada gambar 6 . Peserta diingatkan bahwa teknik penyambungan ini bersifat permanen. Sedangkan cara kedua adalah dengan double neple. Peserta diberi pemahaman singkat bahwa teknik ini juga

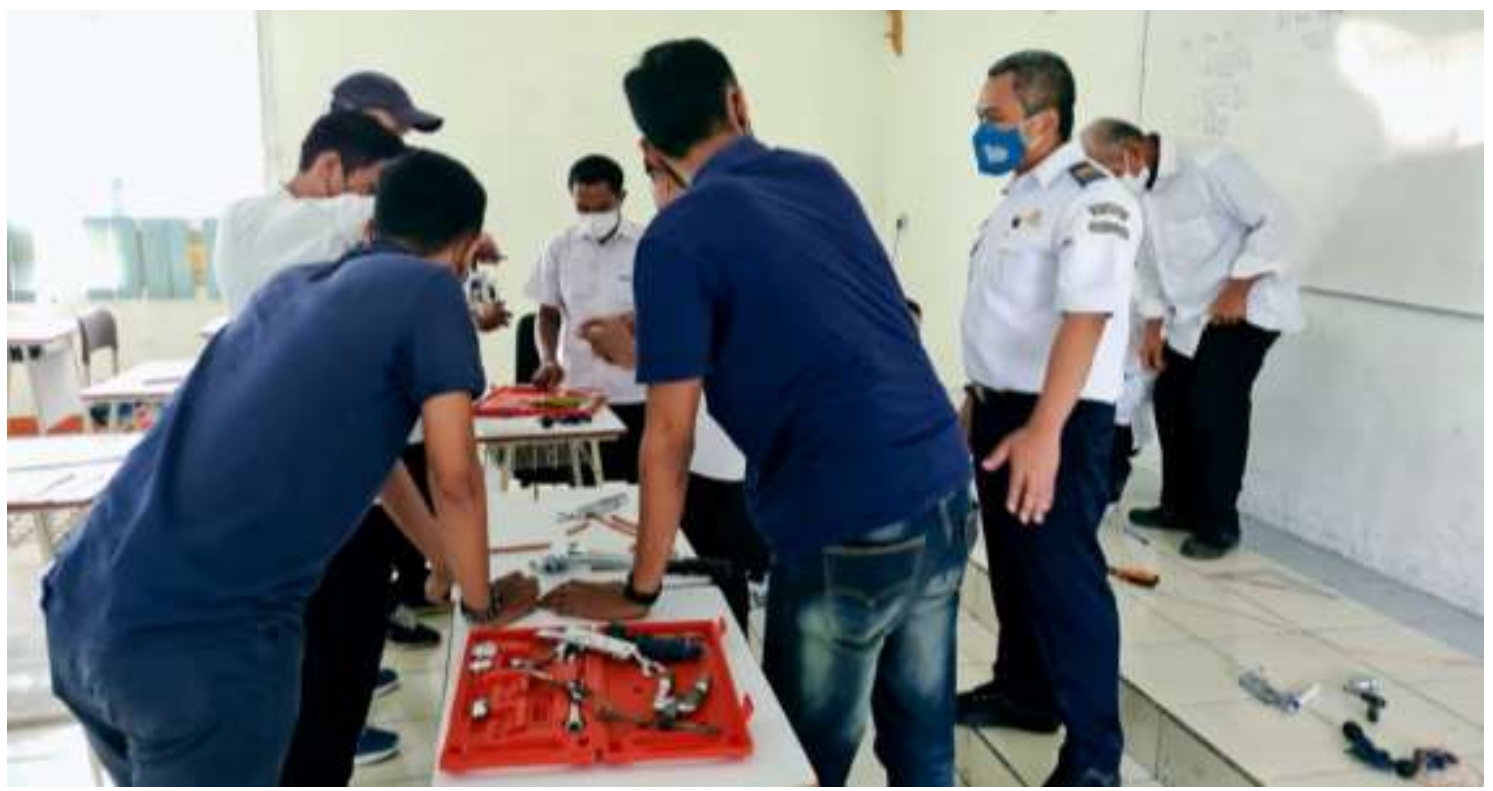




\section{Gambar 5. Praktek Flaring}

penting karena pada saat tertentu (service besar) sebagian unit AC (bagian indoor) perlu dilepas tanpa perlu membongkar seluruh instalasi AC. Contoh penempatan teknik ini adalah dibelakang unit indoor AC seperti ditunjukkan pada gambar 7 .
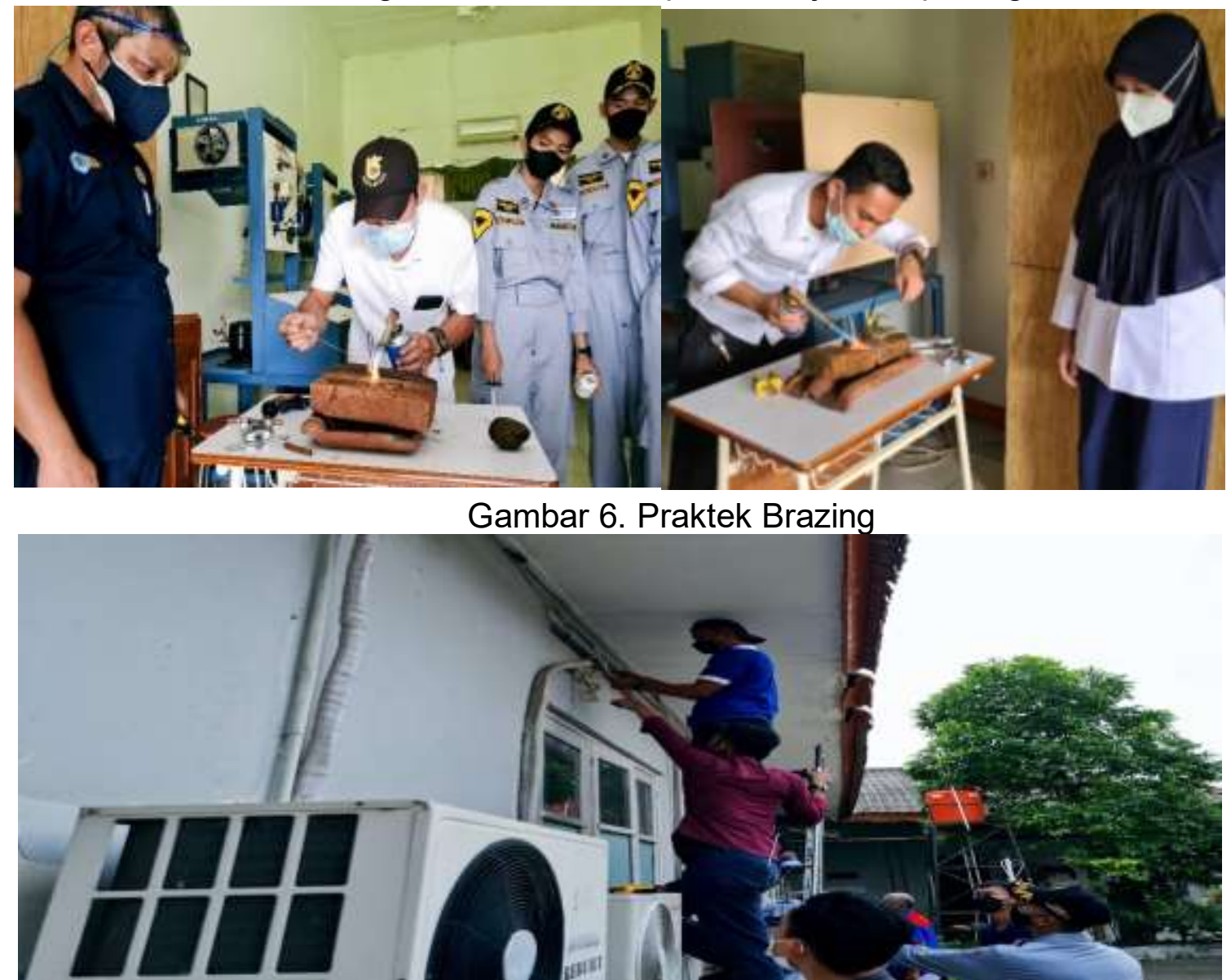

Gambar 7. Penempatan Double Nepel

Di hari kedua pelatihan, peserta diajak mempraktekkan cara melakukan perawatan berkala. Sebelum memulai praktek, peserta diberikan penjelasan singkat tentang langkah-langkah atau prosedur melakukan perawatan. Dalam proses perawatan AC, peserta pelatihan diberikan pemahaman tentang pentingnya mengindentifikasi unit $A C$ dari spesifikasi nomor seri yang tertera pada unit AC. Untuk itu peserta diajak mempraktekan metode sederhana mengidentifikasi unit AC dan cara mencatat riwayat perawatan unit AC tersebut seperti ditunjukkan pada Gambar 8.

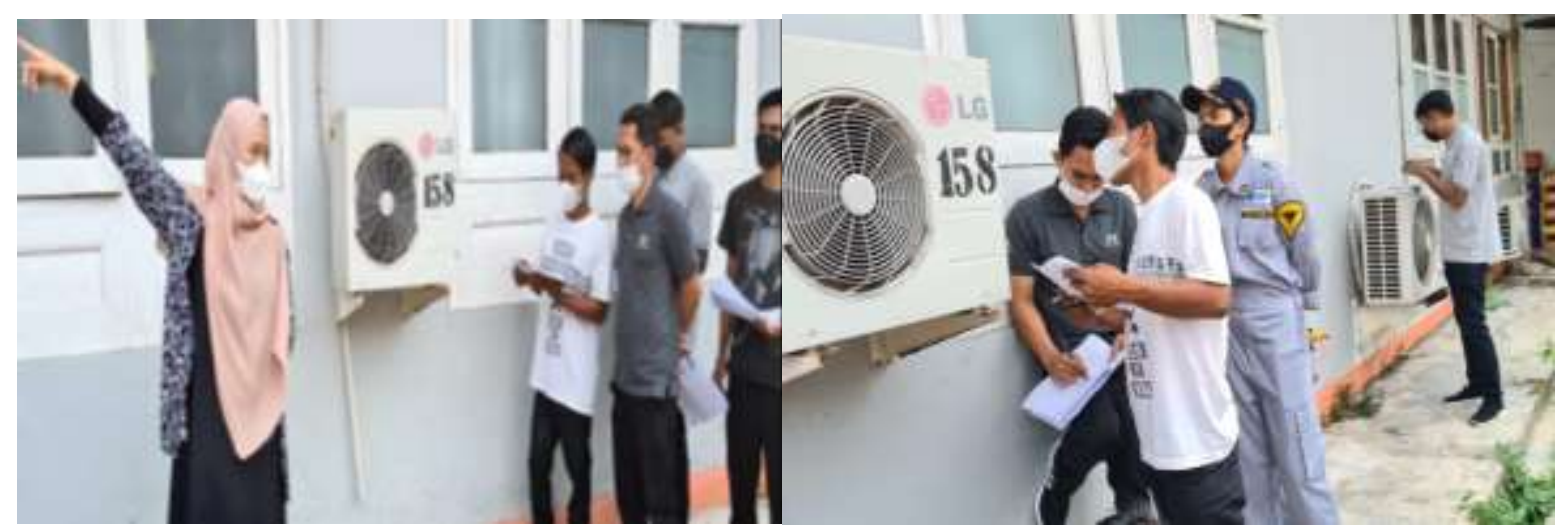


Gambar 8. Identifikasi Unit AC.

Keterampilan selanjutnya yang ditunjukkan kepada peserta adalah membongkar unit indoor AC. Langkah ini diperlukan saat unit AC membutuhkan perawatan berupa service besar.

Langkah selanjutnya dalam proses service $A C$ yang diajarkan ke peserta pelatihan adalah pencucian AC menggunakan air bertekanan. Proses pencucian dapat dilakukan dengan 2 cara. Pertama, unit indoor tetap terpasang pada tempatnya seperti ditunjukkan pada gambar 9 . Teknik ini biasa dilakukan untuk perawatan rutin AC. Cara kedua adalah dengan mencuci unit indoor yang sudah dilepas. Teknik yang ditunjukkan pada gambar 10 .

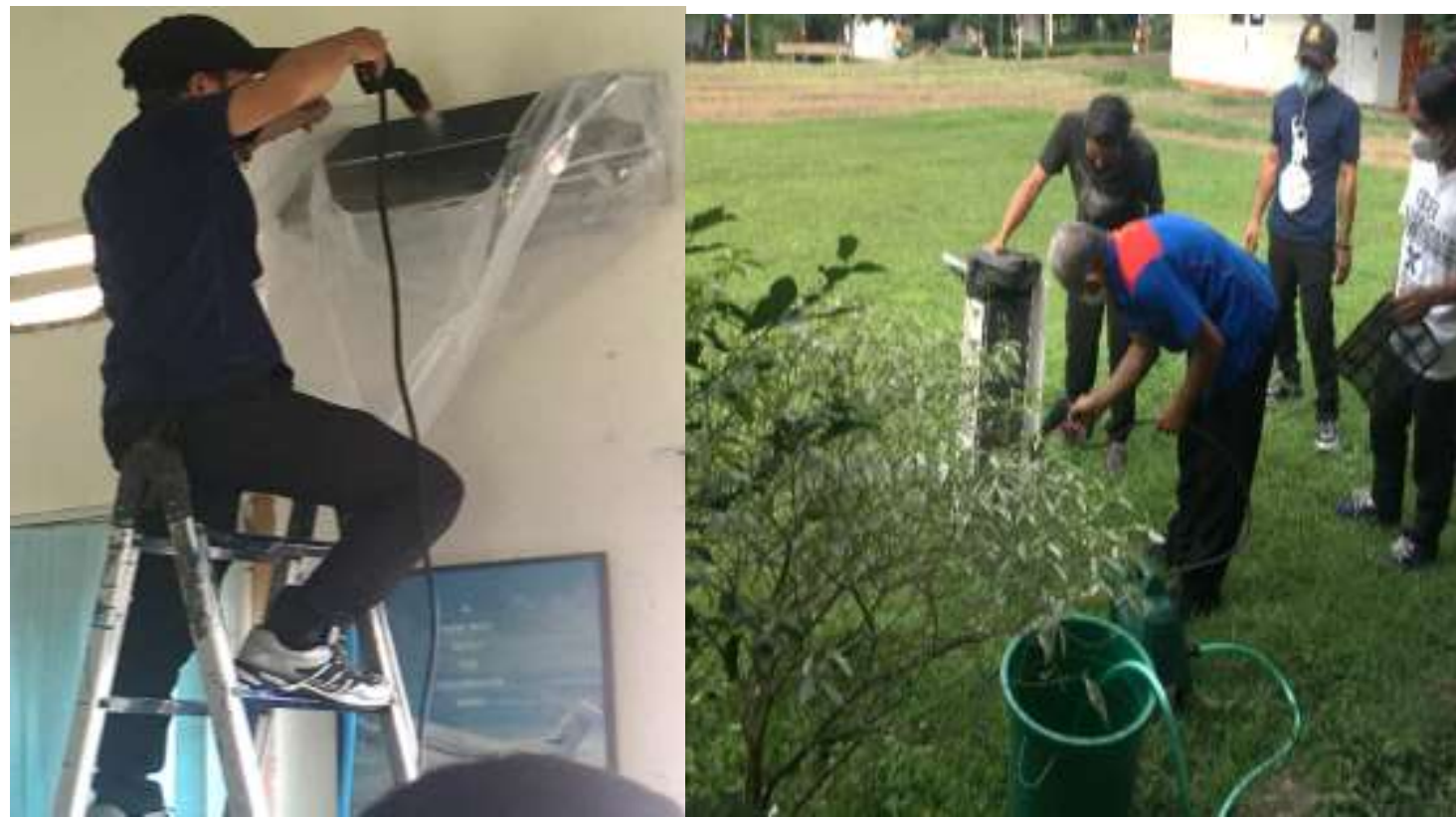

Gambar 9. Pencucian Unit Indoor terpasang/terlepas

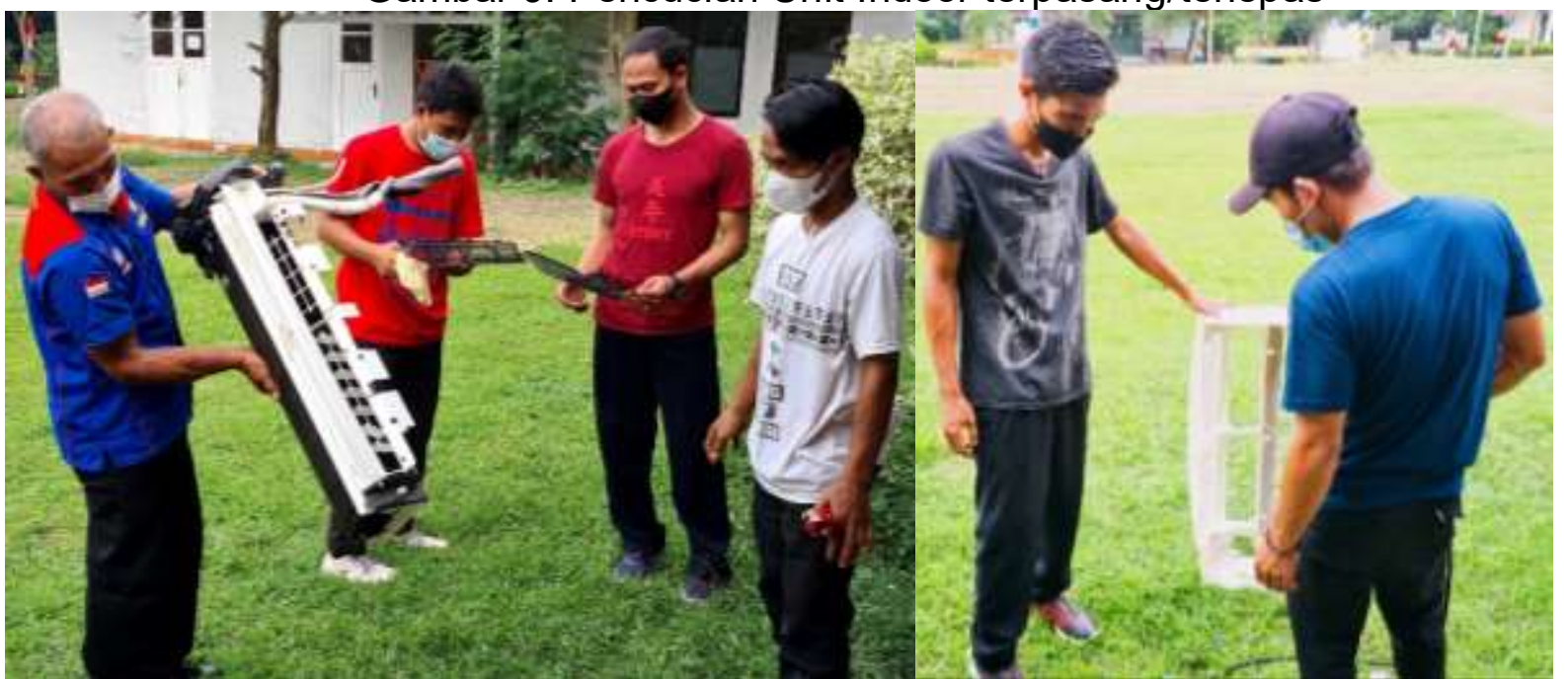

Gambar 10. Pengeringan Unit AC

Setelah selesai pencucian, peserta pelatihan diminta untuk memastikan bahwa unit AC cukup kering sebelum dipasang kembali seperti ditunjukkan pada gambar 11 . Prosedur ini dilakukan untuk mencegah korsleting atau short circuit. 


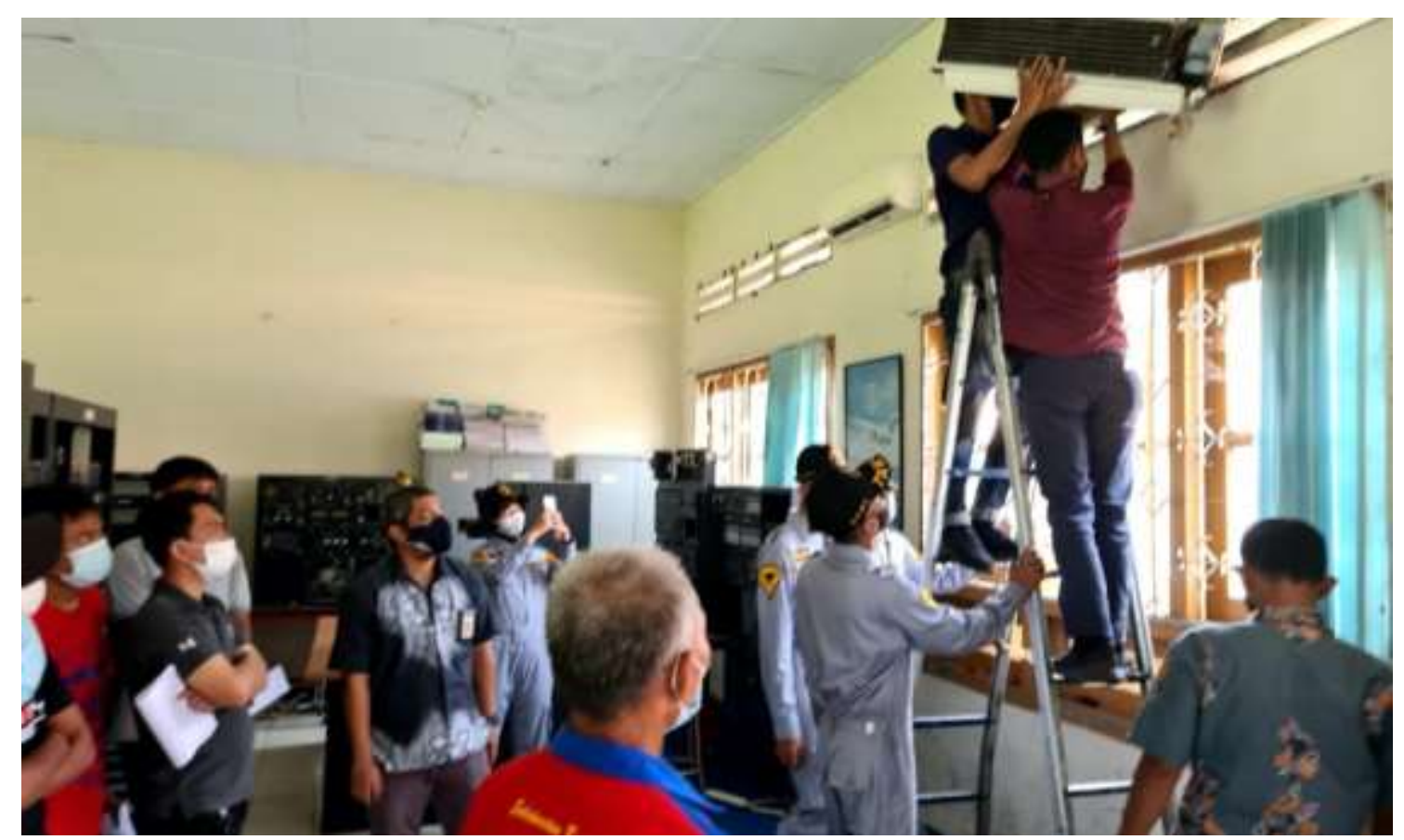

Gambar 11. Re-instal Unit AC

Selanjutnya peserta pelatihan diminta mengikuti prosedur pemasangan kembali (reinstal) unit AC ke posisi semula. Peserta diminta tetap memperhatikan hal-hal kecil seperti posisi baut, posisi kabel, dan posisi pipa kembali seperti pada posisi semula.

Untuk proses perawatan dengan melepas unit indoor AC seperti yg biasa dilakukan untuk service besar, peserta diajarkan untuk memastikan tekanan refrigerant atau freon cukup. Pengukuran dilakukan menggunakan manometer atau manifold gauge seperti ditunjukkan pada gambar 12. Apabila tekanan kurang maka peserta pelatihan diminta menambahkan freon melalui unit outdoor sesuai spesifikasi unit AC.

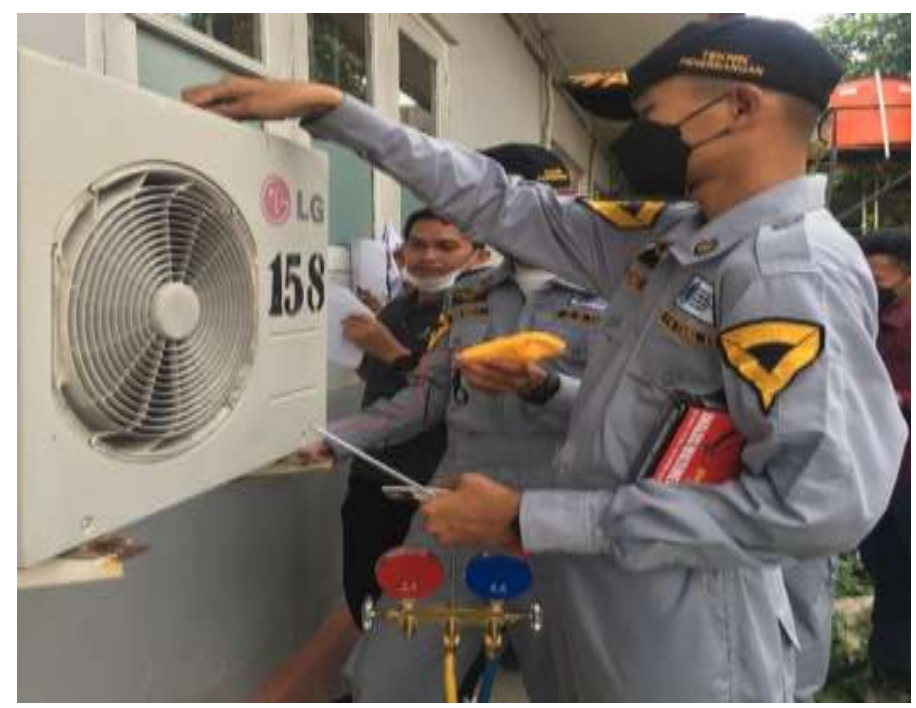

Gambar 12. Pengukuran tekanan AC.

\section{Evaluasi Kegiatan Pelatihan}

Prosedur perawatan AC yang dipelajari peserta pelatihan kali ini dibatasi pada langkah-langkah dasar dalam melakukan perawatan/service AC secara rutin ataupun berkala. Sedangkan dari hasil evaluasi kegiatan yang dilakukan melalui survei dan 
wawancara peserta, tim PKM menemukan bahwa dibutuhkan juga keterampilan troubleshooting atau pemecahan masalah pada saat ditemukan sebuah unit AC bekerja tidak normal.

\section{Kesimpulan}

Selesainya kegiatan Pengabdian Kepada Masyarakat ini memberikan beberapa hasil kesimpulan. Pertama, peserta mendapat pengetahuan teoritis dan keterampilan tentang pemeliharaan dan perawatan AC. Kedua, peserta mendapatkan praktek langsung bagaimana pemeliharaan, perawatan AC. Dari hasil evaluasi kegiatan juga ditemukan bahwa masyarakat berminat mengikuti kegiatan pelatihan dengan metode sejenis.

Dengan melihat masih adanya kelompok masyarakat di sekitar PPIC yang tidak memiliki pengetahuan dan keterampilan untuk bekerja, kegiatan Pengabdian kepada Masyarakat dapat dilakukan kembali dengan cara memberikan pelatihan keterampilan praktis yang dibutuhkan di dunia kerja. Dengan demikian salah satu kewajiban Tridharma Perguruan Tinggi dapat terpenuhi sekaligus memberikan peluang lebih besar kepada masyarakat untuk mengembangkan diri sebagai modal kerja.

\section{Ucapan Terimakasih}

Kegiatan pengabdian kepada masyarakat yang berjudul "Pelatihan Perawatan/ Service AC Untuk Masyarakat Sekitar Politeknik Penerbangan Indonesia Curug" didanai dari DIPA Politeknik Penerbangan Indonesia Curug tahun Anggaran 2021 dengan nomor Kontrak 007/SPK/PKM/PPK/8/PPI-2021 tanggal 2 Agustus 2021. Dengan terlaksananya kegiatan pengabdian kepada masyarakat ini ungkapan terimakasih penulis sampaikan kepada pihak perangkat desa dan masyarakat yang telah mengikuti kegiatan PKM ini dengan baik serta kepada Pusat Penelitian dan Pengabdian Masyarakat PPI Curug yang telah mewadahi program pengabdian ini sehingga berjalan dengan baik dan lancar.

\section{Referensi}

Buku, P., Elektrikal, A., Pesawat, E., Bagi, U., Smk, G., Sihono, P., ... Curug, I. (2021). Pendalaman Buku Ajar Elektrikal dan Elektronika Pesawat Udara Bagi Guru SMK Penerbangan. Jurnal Pengabdian Kepada Masyarakat (JPKM) Langit Biru, 2, 4654. https://doi.org/10.54147/JPKM.V2I01.462

Hendriarto, P., Mursidi, A., Kalbuana, N., Aini, N., \& Aslan, A. (2021). Understanding the Implications of Research Skills Development Framework for Indonesian Academic Outcomes Improvement. Jurnal Iqra' : Kajian IImu Pendidikan, 6(2), 5160. https://doi.org/10.25217/JI.V6I2.1405

Husodo, B., Elektro, N. S.-J. T., \& 2014, undefined. (n.d.). Analisa audit konsumsi energi sistem hvac (heating, ventilasi, air conditioning) di terminal 1a, 1b, dan 1c bandara soekarno-hatta. publikasi.mercubuana.ac.id. Diambil dari https://publikasi.mercubuana.ac.id/files/journals/4/articles/761/submission/origina l/761-1760-1-SM.pdf 
Kalbuana, N., \& Kurnianto, B. (2011). Tinjauan Terhadap Motifasi Kaitannya Dengan Produktifitas Kerja Petugas Air Traffic Control Bandar Udara Soekarno-Hatta. Langit Biru: Jurnal Ilmiah Aviasi, 4(9), 9-16. Diambil dari http://journal.ppicurug.ac.id/index.php/jurnal-ilmiah-aviasi/article/view/307

Kalbuana, N., Prasetyo, B., Kurnianto, B., Saputro, R., Kurniawati, Z., Utami, S., ... Legok, K. (2021). Liquidity Effect, Profitability Leverage to Company Value: A Case Study Indonesia. European Journal of Molecular \& Clinical Medicine, 7(11), 2800-2822. Diambil dari https://ejmcm.com/article_6290.html

Nawang Kalbuana, B. K. R. S. O. H. S. U. R. A. W. (2020). The Effect of Audit Quality, Managerial ownership, Institutional ownership, and Intellectual Capital toward Earning Management on Transportation Corporations in Indonesia. Solid State Technology, 63(5), 9176-9184. Diambil dari http://www.solidstatetechnology.us/index.php/JSST/article/view/8056

Pattiapon, M. L. (Marcy ), Kembauw, E. (Esther ), Siregar, Z. H. (Zufri ), Hardono, J. (Joko ), Sarasanty, D. (Diah ), Sihombing, A. T. (Alexander ), ... Rochmi, A. (Alfi ). (2021). Ekonomi Teknik. https://doi.org/10.0/CSS/ALL.CSS

Pengabdian dan Edukasi Sekolah, J., JAWA TENGAH DAN SEKITARNYA Sihono, P. DI, Fatkulloh, A., Saputro, R., Herwanto, D., Kalbuana, N., ... Penerbangan Indonesia Curug, P. (2021). Pemantapan Dan Refreshing Materi Electrical \& Electronik Untuk Guru Smk Penerbangan Di Jawa Tengah Dan Sekitarnya. Jubaedah: Jurnal Pengabdian dan Edukasi Sekolah (Indonesian Journal of Community Services and School Education), 1(1), 12-19. https://doi.org/10.46306/JUB.V1I1.2

Prasetyo, B., Rohman, T., Solihin, S., Sundoro, S., \& Kalbuana, N. (2021). Sosialisasi Kawasan Keselamatan Operasi Penerbangan (KKOP). Jurnal Pengabdian Kepada Masyarakat (JPKM) Langit Biru, 2, 31-38. https://doi.org/10.54147/JPKM.V2101.451

Ridhuan, K., \& Refai, A. (2013). Analisa Kebutuhan Beban Pendingin Dan Daya Alat Pendingin Ac Untuk Aula Kampus 2 Um Metro. Turbo: Jurnal Program Studi Teknik Mesin, 2(2), 7. https://doi.org/10.24127/TRB.V2I2.26

Sumeru, S., \& Sutandi, T. (2018). Pelatihan Pemasangan Dan Perbaikan Pengkondisi Udara Sebagai Bekal Berwirausaha Di Kota Cimahi. Jurnal DIFUSI, 1(1). https://doi.org/10.35313/DIFUSI.V1I1.1029 